\title{
Knowledge Management in EURAD: the Roadmap
}

\author{
Tara Beattie ${ }^{1}$, Paul Carbol ${ }^{2}$, Bernd Grambow ${ }^{3}$, Tobias Knuuti ${ }^{4}$, Louise Théodon ${ }^{5}$, and Piet Zuidema ${ }^{6}$ \\ ${ }^{1}$ TB Environmental, Belfast, UK \\ ${ }^{2}$ European Commission, JRC, Karlsruhe, Germany \\ ${ }^{3}$ Subatech, IMT Atlantique, Nantes, France \\ ${ }^{4}$ BGE, Peine, Germany \\ ${ }^{5}$ Andra, Châtenay-Malabry CEDEX, France \\ ${ }^{6}$ Zuidema Consult, Würenlos, Switzerland
}

Correspondence: Piet Zuidema (piet.zuidema@zuidema-consult.ch)

Published: 10 November 2021

\begin{abstract}
Knowledge management (KM) is a core activity of the European Joint Programme on Radioactive Waste Management (EURAD), which has driven the development of the EURAD Roadmap, a roadmap for the implementation of radioactive waste management (RWM) leading to geological disposal, using the experiences of advanced national and EU programmes. Because these programmes have been developed over more than 40 years and have adopted different technical and strategic approaches to deep geological repository (DGR) development, the roadmap has been structured to capture largely generic best practice in its presentation of programme Phasing and Thematic goals breakdown structure:

- 5 Phases of Implementation: Initiation, Site Selection, Site Characterization, Construction, and Operations and Closure. For each phase the roadmap explains how activities and existing knowledge are used to fulfil generic safety and implementation goals common across RWM programmes.

- 7 themes: Programme Management, Predisposal, Engineered Barrier Systems, Geoscience, Design and Optimisation, Siting and Licensing, and Safety Case. Each theme is further elaborated into sub-themes and domains.
\end{abstract}

The intention of the EURAD roadmap is to provide information and guidance to three primary user groups:

1. Organisations that are developing or updating their national RWM programmes with the objective of moving towards deep geological disposal of some of their wastes and requiring information on the steps involved;

2. Organisations with advanced RWM and DGR programmes that require an informative training tool for new staff and a means of propagating knowledge across the groups involved in diverse activities;

3. All organisations concerned with identifying potential future gaps in capabilities that could hinder implementation of their DGR programmes in decades to come.

We recognize that there is not a unique route through the roadmap - like any roadmap, it can be used to stimulate consideration of alternative options and can be adapted by each Member State to suit national priorities. Because of its generic nature, the EURAD roadmap will be populated with content that is common to all programmes, creating a basis and strategy for a long-term project of Knowledge Management and Networking in RWM. The current focus is on signposting to existing content and the generation of new content to fill identified gaps for State of Knowledge, State of the Art, Guidance, Training and active Networks or Communities of Practice.

Kurzfassung. Wissensmanagement spielt eine zentrale Rolle in EURAD (dem „European Joint Programme on Radioactive Waste Management“ - RWM), und hat die Entwicklung der EURAD-Roadmap vorangetrieben. Diese Roadmap soll die Implementierung des Managements von radioaktiven Abfällen mit dem Ziel der geologischen Endlagerung unterstützen und berücksichtigt dabei die Erfahrungen fortgeschrittener nationaler Programme und die Resultate wichtiger EU-Projekte. Da sich diese Programme und Projekte über einen Zeitraum 
von mehr als 40 Jahren entwickelt haben und unterschiedliche technische und strategische Ansätze für die Entwicklung tiefengeologischer Endlager verfolgen, wurde die Roadmap so aufgebaut, dass sie weitgehend allgemeingültige „Best-Practices“ darstellt, gegliedert in Programmphasen und deren inhaltliche Ziele bzw. Themen:

- 5 Phasen der Implementierung: Initiierung, Standortauswahl, Standortcharakterisierung, Bau, sowie Betrieb und Stilllegung. Für jede Phase wird in der Roadmap ausgeführt, welche themenbezogenen Aktivitäten notwendig sind und wie das dazu vorhandene Wissen genutzt wird, um in jeder Phase die für erfolgreiche Entsorgungsprogramme üblichen Ziele zu erreichen.

- die in jeder Phase relevanten Themen: Programmmanagement, Abfallbehandlung, technische Barrierensysteme, Geowissenschaften, Auslegung und Optimierung, Standortauswahl und Genehmigungsverfahren, sowie Sicherheitsnachweis. Jedes Thema ist untergliedert in 2 weitere Ebenen: „sub-themes“ und „domains“.

Die EURAD-Roadmap zielt darauf ab, 3 wesentlichen Nutzergruppen Informationen und Anleitungen zur Verfügung zu stellen:

1. Organisationen, die ihre nationalen Entsorgungsprogramme mit dem Ziel der geologischen Endlagerung für einige ihrer Abfälle entwickeln oder aktualisieren, und hierfür Informationen über die entsprechenden Schritte benötigen.

2. Organisationen mit weit entwickelten Entsorgungs- und Endlagerprogrammen, die ein informatives Schulungsinstrument für neue Mitarbeiter*innen und ein Instrument zur Wissensvermittlung zwischen beteiligten Gruppen benötigen.

3. Allen Organisationen, die sich mit der Ermittlung möglicher künftiger Kompetenzdefizite befassen, welche die Umsetzung ihrer Entsorgungsprogramme in den kommenden Jahrzehnten beeinträchtigen könnten.

Wir sind uns bewusst, dass es nicht einen einzigen Weg durch die Roadmap gibt - wie jede Roadmap kann sie als Anregung zur Prüfung alternativer Optionen dienen und kann von jedem Mitgliedstaat an nationale Prioritäten angepasst werden. Aufgrund ihres allgemeinen Charakters wird die EURAD-Roadmap mit Wissensinhalten gefüllt, die für alle Programme üblich sind, um so eine Grundlage und Strategie für eine langfristige Zusammenarbeit im Bereich Wissensmanagement und Networking zum Management von radioaktiven Abfällen zu schaffen. Der Schwerpunkt liegt derzeit zum einen darauf, die Roadmap mit extern bestehenden Wissensinhalten (z. B. in Form von Dokumenten) zu verknüpfen, sowie zum anderen darin, erkannte Lücken hinsichtlich verfügbarer Inhalte in den Bereichen Wissensstand, Stand der Technik, Guidance, Training und aktive Netzwerke bzw. Anwendergemeinschaften durch die Erstellung neuer Inhalte zu schließen.

Financial support. This research has been supported by the European Commission, Horizon 2020 Framework Programme (grant no. EURAD (847593)). 